Aspirasi: Jurnal Masalah-Masalah Sosial | Volume 10, No. 1 Juni 2019

ISSN: 2086-6305 (print) ISSN: 2614-5863 (electronic)

DOI: https://doi.org/10.22212/aspirasi.v7il.1084

link online: http:/jurnal.dpr.go.id/index.php/aspirasi/index

\title{
PERAN PROGRAM KELUARGA HARAPAN DALAM PENURUNAN ANGKA KEMATIAN IBU DI PROVINSI JAMBI DAN PROVINSI KALIMANTAN SELATAN
}

\author{
The Role of Conditional Cash Transfer Programme in The Reduction of Maternal \\ Mortality Rate in Jambi Province and South Kalimantan Province)
}

\author{
Sali Susiana \\ sali.susiana@dpr.go.id \\ Pusat Penelitian Badan Keahlian DPR RI \\ Jl. Gatot Subroto, Senayan, Jakarta
}

Naskah Diterima: 28 September 2018 | Naskah direvisi: 10 Juni 2019 | Naskah diterbitkan: 29 Juni 2019

\begin{abstract}
The study was conducted with a qualitative approach to see how the Family Hope Program (PKH) played a role in decreasing Maternal Mortality Rate (MMR) in Jambi and South Kalimantan Provinces. Data were obtained from interviews with PKH management officials, PKH assistants and PKH recipients who were pregnant. It was found that there was no direct connection between PKH and the decline in MMR, because there was no detailed provision regarding the percentage of cash received from $P K H$ that had to be spent to improve the nutritional quality of $P K H$ recipients, thus influencing the quality of maternal health and reducing MMR. In addition, not all pregnant women check themselves at a minimum of 4 times during pregnancy. The two provinces do not hold special programs for pregnant women receiving $P K H$. Nevertheless, there were several efforts to improve the quality of health and nutrition of pregnant women from the Ministry of Health, namely through the provision of blood tablets and biscuits, as well as the implementation of the Class for Pregnant Women. To increase the effectiveness of $P K H$ in reducing $M M R$, it is necessary to periodically provide assistance and monitoring to PKH recipients who were pregnant.
\end{abstract}

Keywords: women's reproductive health, Hope Family Program, Maternal Mortality Rate.

Abstrak: Penelitian dilakukan dengan pendekatan kualitatif untuk melihat bagaimana peran Program Keluarga Harapan (PKH) dalam penurunan Angka Kematian Ibu (AKI) di Provinsi Jambi dan Kalimantan Selatan. Data diperoleh dari wawancara kepada pejabat pengelola PKH, pendamping PKH dan ibu hamil penerima PKH. Ditemukan bahwa tidak terdapat kaitan secara langsung antara PKH dan penurunan AKI, karena tidak ada ketentuan yang rinci mengenai persentase uang tunai yang diterima dari PKH yang harus dibelanjakan untuk meningkatkan kualitas gizi ibu hamil penerima PKH, sehingga berpengaruh pada kualitas kesehatan ibu hamil dan penurunan AKI. Selain itu, tidak semua ibu hamil memeriksakan diri minimal 4 kali selama kehamilan. Kedua provinsi tidak menyelenggarakan program khusus bagi ibu hamil penerima PKH. Meskipun demikian, ada beberapa upaya untuk meningkatkan kualitas kesehatan dan gizi ibu hamil yang menjadi program Kementerian Kesehatan, yaitu melalui pemberian tablet tambah darah dan biskuit, serta penyelenggaraan Kelas Ibu Hamil. Untuk meningkatkan efektivitas PKH dalam menurunkan AKI, perlu dilakukan pendampingan dan monitoring secara berkala kepada ibu hamil penerima PKH.

Kata kunci: kesehatan reproduksi perempuan, Program Keluarga Harapan, Angka Kematian Ibu 


\section{Pendahuluan}

Meningkatkan kesehatan ibu adalah butir kelima dari Tujuan Pembangunan Milenium/ Millennium Development Goals (MDGs) yang harus dicapai oleh 191 negara anggota PBB pada tahun 2015, termasuk Indonesia. Meningkatkan kesehatan ibu (selanjutnya disebut MDGs 5) terdiri dari dua target, yaitu: (1) mengurangi 2/3 Angka Kematian Ibu (AKI) saat melahirkan (1990-2015); dan (2) akses terhadap pelayanan kesehatan standar hingga tahun 2015. Khusus untuk Indonesia, tujuan yang ditetapkan dalam MDGs 5 ada tiga poin, meliputi: pertama, menurunkan AKI dari 390 per 100.000 kelahiran hidup pada tahun 1990 menjadi 102 pada tahun 2015; kedua, meningkatkan cakupan persalinan oleh tenaga kesehatan dari 40,7\% (1990) menjadi 100\% (2015); dan ketiga, seluruh perempuan usia 15-49 tahun yang pernah menikah menggunakan alat/cara kontrasepsi (universal access).

AKI adalah jumlah kematian ibu selama masa kehamilan, persalinan dan nifas yang disebabkan oleh kehamilan, persalinan, dan nifas atau pengelolaannya tetapi bukan karena sebab-sebab lain seperti kecelakaan atau terjatuh di setiap 100.000 kelahiran hidup. Menurut Kementerian Kesehatan, indikator ini tidak hanya mampu menilai program kesehatan ibu, namun juga mampu menilai derajat kesehatan masyarakat, karena sensitivitasnya terhadap perbaikan pelayanan kesehatan, baik dari sisi aksesibilitas maupun kualitas.

Hingga tahun 2015, ternyata target tersebut tidak dapat dicapai. Hal ini memang sudah diprediksi sebelumnya. Dengan prediksi linier AKI, Kementerian Kesehatan memperkirakan pada tahun 2015 Indonesia baru akan mencapai angka 161 per 100.000 kelahiran hidup. Data resmi dari Kementerian Perencanaan Pembangunan Nasional/Bappenas (2010:2) menyatakan AKI telah menurun dari 390 pada tahun 1991 menjadi 228 per 100.000 kelahiran hidup pada tahun 2007. Data ini berbeda dengan laporan dari United Nations Population Fund (UNFPA) yang menyatakan bahwa AKI di Indonesia pada tahun 2009 masih sebesar 420.000 per 100.000 kelahiran hidup. Data terakhir dari United Nations Development
Programme (UNDP) yang terdapat dalam indeks pembangunan manusia/human development index tahun 2017 menunjukkan AKI di Indonesia masih sebesar 305 per 100.000 kelahiran hidup (Fauzi, 2017). Adapun hasil Survei Demografi Kesehatan Indonesia 2012 menunjukkan AKI sebesar 359 per 100.000 kelahiran hidup. Data dari Kementerian Kesehatan tahun 2016 menunjukkan AKI kembali mengalami penurunan menjadi 305 per 100.000 kelahiran hidup berdasarkan hasil Survei Penduduk Antar Sensus (SUPAS) 2015 (Kementerian Kesehatan, 2017:102).

Sejak berakhirnya MDGs pada 2015 dan berlakunya Sustainable Development Goals (SDGs), upaya penurunan AKI memang masih menjadi perhatian khusus di dunia. Salah satu perubahan mendasar yang dibawa oleh SDGs adalah prinsip "tidak ada seorang pun yang ditinggalkan". Artinya cakupan target dan pelayanan dalam era SDGs lebih menyeluruh (100\%) bila dibandingkan pada saat era MDGs yang hanya setengahnya (Hoelman dkk, 2015: 15).

Terkait dengan AKI, mengingat hingga saat ini AKI masih cukup tinggi dan masih jauh dari target, telah dilakukan beberapa upaya untuk menurunkan AKI, baik yang dilaksanakan oleh Kementerian Kesehatan sebagai kementerian yang bertanggung jawab menangani bidang kesehatan, maupun kementerian lainnya. Salah satunya adalah Program Keluarga Harapan (PKH) dari Kementerian Sosial, sebuah program pemberian bantuan sosial bersyarat kepada Keluarga Miskin (KM) yang ditetapkan sebagai Keluarga Penerima Manfaat (KPM). Program ini dapat dikatakan mendukung upaya penurunan AKI, karena salah satu fokusnya adalah ibu hamil yang terdapat dalam rumah tangga miskin.

Meskipun tidak berkaitan secara langsung, namun PKH dapat dipandang sebagai salah satu upaya untuk menurunkan AKI, karena melalui $\mathrm{PKH}$, ibu hamil yang termasuk dalam rumah tangga miskin wajib melakukan pemeriksaan kandungan minimal 4 kali di fasilitas pelayanan kesehatan. Oleh karena itu, penelitian ini ingin mengetahui bagaimana hubungan antara PKH dan penurunan AKI. Permasalahan tersebut 
selanjutnya dijabarkan ke dalam pertanyaan penelitian berikut: pertama, bagaimana peran PKH dalam penurunan AKI? Kedua, upaya apa saja yang dapat dilakukan untuk meningkatkan efektivitas PKH dalam menurunkan AKI? Adapun penelitian ini bertujuan untuk menjawab dua pertanyaan diatas, yaitu (1) untuk mengetahui peran PKH dan penurunan AKI; dan (2) upaya yang dapat dilakukan untuk meningkatkan efektivitas PKH dalam menurunkan AKI.

Dengan mengetahui hubungan antara PKH dan penurunan AKI dan upaya yang dapat dilakukan untuk meningkatkan efektivitas PKH dalam menurunkan AKI, diharapkan hasil penelitian ini dapat memberikan bahan masukan kepada DPR khususnya Komisi VIII dalam melaksanakan fungsi pengawasan yang terkait dengan $\mathrm{PKH}$ dan peningkatan kualitas hidup perempuan serta Komisi IX dalam melaksanakan fungsi pengawasan yang terkait dengan bidang kesehatan, terutama kesehatan reproduksi perempuan dan upaya penurunan AKI yang menjadi salah satu target Pemerintah, dalam hal ini Kementerian Kesehatan.

Secara umum penelitian ini menggunakan pendekatan kualitatif. Pendekatan ini dipilih karena sifat pendekatan kualitatif yang terbuka dan fleksibel. Melalui pendekatan ini diharapkan dapat diperoleh masukan sebanyak-banyaknya dari para narasumber dan informan, sehingga dapat diperoleh gambaran yang utuh mengenai hubungan antara PKH dan penurunan AKI.

Sesuai dengan pendekatan yang dipakai, yaitu pendekatan kualitatif, data dikumpulkan melalui wawancara terbuka kepada narasumber dan informan penelitian. Sejalan dengan metode pengumpulan data yang digunakan, yaitu wawancara mendalam dan studi dokumen yang relevan dengan topik penelitian, maka peneliti melakukan wawancara kepada pejabat di instansi/ Satuan Kerja Perangkat Daerah (SKPD) yang menangani PKH, yaitu Dinas Sosial dan Dinas Kesehatan. Selain itu wawancara juga dilakukan kepada Pendamping PKH dan perempuan penerima PKH (ibu hamil).

Data yang telah terkumpul melalui serangkaian teknik pengumpulan data tersebut dianalisis secara kualitatif. Ada tiga langkah yang dilakukan dalam analisis data kualitatif ini, yaitu: reduksi data, penyajian data, dan penarikan kesimpulan. Reduksi data dilakukan agar data yang berasal dari berbagai sumber itu dapat dipahami. Oleh karena itu, dalam reduksi data ini, peneliti berupaya melakukan penyuntingan dan kategorisasi data sesuai dengan masalah dan tujuan yang telah ditetapkan dalam penelitian ini. Setelah dilakukan reduksi data, langkah selanjutnya adalah penyajian data dan penarikan kesimpulan.

Penelitian dilaksanakan di Provinsi Jambi dan Provinsi Kalimantan Selatan. Provinsi Jambi dipilih karena berdasarkan Profil Kesehatan Indonesia 2016, provinsi ini memiliki keunikan dalam kasus yang terkait dengan AKI. Berdasarkan data dari Kementerian Kesehatan tahun 2016 mengenai cakupan kunjungan pelayanan kesehatan ibu hamil minimal 4 kali (K4), Provinsi Jambi termasuk ke dalam 9 provinsi yang belum mencapai target Rencana Strategis (Renstra) Kementerian Kesehatan sebesar 74\%. Cakupan pelayanan kesehatan ibu hamil K4 Provinsi Jambi baru mencapai 58,06\%. Delapan provinsi lainnya yaitu Maluku Utara, Papua, Nusa Tenggara Timur, Papua Barat, Maluku, Sulawesi Barat, Sulawesi Tenggara, dan Daerah Istimewa Yogyakarta.

Namun demikian, apabila dilihat cakupan imunisasi Tetanus Foksoid Kedua (TT2) pada ibu hamil, data dari sumber yang sama (Kementerian Kesehatan, 2016: 109) menunjukkan bahwa Provinsi Jambi merupakan provinsi kedua yang memiliki cakupan terbesar, yaitu sebesar 94,4\%, di bawah Jawa Barat dengan cakupan sebesar 102,14\%. Demikian pula dengan Kunjungan Nifas Ketiga (KF3), Provinsi Jambi menempati posisi kedua terbesar, yaitu 94,38\%, peringkat kedua setelah Provinsi DKI Jakarta yang memiliki capaian tertinggi sebesar 94,65\% (Kementerian Kesehatan, 2016: 113). Ada pun Provinsi Kalimantan Selatan dipilih untuk mewakili wilayah Indonesia bagian tengah dan provinsi dengan cakupan puskesmas melaksanakan Program Perencanaan Persalinan dan Pencegahan Komplikasi (P4K) yang termasuk dalam kategori 
4 provinsi terendah, yaitu sebesar $67,8 \%$, bersama dengan Provinsi Sumatera Utara, Papua, dan Papua Barat (Kementerian Kesehatan, 2016: 116).

\section{Studi Pustaka}

Penelitian tentang AKI antara lain dilakukan oleh Pertiwi (2012:120) yang menunjukkan bahwa persentase persalinan dibantu oleh dukun, persentase rumah tangga berperilaku hidup bersih dan sehat, dan persentase sarana kesehatan di tiap kabupaten/ kota di Jawa Timur berpengaruh secara signifikan terhadap AKI. Penelitian lain yang dilakukan oleh Aristia (2011) menyatakan bahwa persentase rumah tangga berperilaku hidup bersih sehat berpengaruh secara signifikan terhadap jumlah kematian ibu.

Terkait dengan efektivitas PKH dalam menurunkan AKI, penelitian yang dilakukan oleh Andri Suharyono (2010) menunjukkan bahwa PKH di Kecamatan Ngoro Kabupaten Jombang telah dapat menurunkan AKI dari 180,5 per 100.000 kelahiran hidup pada tahun 2005 menjadi 0 per 100.000 kelahiran hidup di tahun 2008 . Rumusan masalah penelitian ini adalah faktorfaktor apakah yang mempengaruhi keberhasilan implementasi PKH dalam penurunan angka AKI di Kecamatan Ngoro Kabupaten Jombang. Tujuan penelitian ini adalah untuk mengetahui faktor-faktor yang memengaruhi keberhasilan implementasi PKH dalam penurunan AKI di Kecamatan Ngoro Kabupaten Jombang, serta untuk mengetahui seberapa besar pengaruh masing-masing faktor tersebut terhadap keberhasilan implementasi AKI dalam penurunan AKI di Kecamatan Ngoro Kabupaten Jombang. Penelitian ini menggunakan model implementasi Edward, yang terdiri dari faktor komunikasi, sumber daya, disposition, dan struktur birokrasi, yang semuanya merupakan variabel bebas. Sedangkan variabel terikatnya adalah persalinan yang aman dari ibu peserta PKH. Penelitian ini merupakan penelitian yang bersifat eksplanatif, yaitu suatu penelitian yang bertujuan untuk menjelaskan pengaruh variabel bebas $(\mathrm{X})$ yang terdiri dari komunikasi (X1), sumber daya (X2), disposisi sikap, kemauan, komitmen (X3) dan struktur birokrasi (X4) terhadap variabel terikat/ dependen (Y) persalinan yang aman ibu peserta PKH. Analisis data menggunakan statistik analisis regresi. Hasil penelitian menunjukkan faktor komunikasi dan faktor struktur birokrasi memengaruhi keberhasilan implementasi Program PKH dalam penurunan AKI yang bermakna, sedangkan faktor sumber daya dan disposisi/sikap kemauan tidak berpengaruh secara signifikan.

Penelitian lain tentang AKI dilakukan oleh Afsah Novita Sari, berjudul "Analisis Jalur Faktor-faktor yang Mempengaruhi Angka Kematian Ibu di Jawa Timur". Analisis yang digunakan dalam penelitian ini adalah analisis jalur. Hasil penelitian menunjukkan bahwa faktor yang mempengaruhi AKI tidak terlepas dari faktor sosial dalam masyarakat. Besarnya pengaruh langsung variabel ibu hamil yang melakukan K1 (pemeriksaan kandungan 1 kali) adalah sebesar 0.513 (Sari, 2012: 119-132).

\section{Kesehatan Reproduksi Perempuan}

Isu tentang kesehatan reproduksi perempuan telah diakui secara internasional sejak Deklarasi Hak Asasi Manusia Tahun 1968 di Teheran. Pengakuan ini diperkuat dengan Deklarasi Meksiko Tahun 1975 yang merupakan hasil Konferensi Wanita se-Dunia ke-1; Konferensi Wanita se-Dunia ke-2 di Kopenhagen; ke-3 di Nairobi dan ke-4 di Beijing. Dijaminnya hak perempuan atas kesehatan reproduksi dituangkan dalam Pasal 12 Konvensi tentang Penghapusan Segala Bentuk Diskriminasi terhadap Perempuan (Convention on the Elimination of All Forms of Discrimination against Women/ CEDAW) yang telah diratifikasi dengan Undang-Undang Nomor 7 Tahun 1984 tentang Pengesahan Konvensi mengenai Penghapusan Segala Bentuk Diskriminasi terhadap Wanita pada tanggal 24 Juli 1984.

Berbagai persoalan yang dialami oleh perempuan dalam bidang kesehatan merupakan salah satu faktor yang memunculkan pemikiran baru yang berorientasi melindungi hak reproduksi perempuan. Badan Kesehatan Dunia (World 
Health Organization/WHO) memberikan definisi bahwa kesehatan reproduksi menyangkut proses, fungsi, dan sistem reproduksi pada seluruh tahap kehidupan (Budi Wahyuni, 1997: 55). Mengacu pada definisi tersebut, Konferensi Internasional tentang Kependudukan dan Pembangunan (International Conference on Population and Development/ICPD) tahun 1994 di Kairo merumuskan kesehatan reproduksi sebagai "keadaan sehat dan sejahtera secara fisik, mental, dan sosial bukan karena ketiadaan penyakit dan kecacatan yang berkaitan dengan fungsi, sistem, dan proses-prosesnya" ( Rahman, 2006: 520).

Indonesia merupakan salah satu negara peserta dalam konferensi ICPD. Konferensi tersebut sebagaimana dinyatakan Anita Rahman (2006: 520) menghasilkan keputusan yang terdiri atas 10 program kesehatan reproduksi, berupa kesehatan primer yang harus diperhatikan oleh semua negara, termasuk Indonesia, antara lain: a. Pelayanan sebelum, semasa kehamilan, dan pascakehamilan; b. Pelayanan Keluarga Berencana yang optimal; c. Pelayanan aborsi; dan d. Pelayanan dan pemberian komunikasi, informasi, dan edukasi (KIE) yang berkaitan dengan kesehatan reproduksi.

Di samping 10 program kesehatan reproduksi tersebut, Anita Rahman (2006: 520) menyatakan bahwa dalam Deklarasi ICPD juga diakui adanya hak reproduksi perempuan, yaitu: a. Hak individu untuk menentukan kapan ia akan mempunyai anak, berapa jumlah anak, dan berapa lama jarak tiap kelahiran; b. Hak untuk mendapat pelayanan yang berkaitan dengan fungsi reproduksinya; c. Hak untuk mendapatkan KIE yang berkaitan dengan hak tersebut; dan $\mathrm{d}$. Hak melakukan kegiatan seksual tanpa paksaan, diskriminasi, dan kekerasan. Keempat hak reproduksi ini dikukuhkan lagi dalam Deklarasi Beijing Tahun 1995 dalam Pasal 96. Tujuan utama dua kesepakatan internasional tersebut adalah untuk mengurangi AKI dan kesakitan/kecacatan akibat aborsi yang tidak aman (Rahman, 2006: 520).

Masalah yang berkaitan dengan kehamilan dan persalinan, termasuk AKI tidak dapat dilepaskan dari berbagai faktor yang mempengaruhinya, antara lain derajat kesehatan ibu dan kesiapan untuk hamil, pemeriksaan antenatal (masa kehamilan), pertolongan persalinan dan perawatan segera setelah persalinan, serta faktor sosial budaya (Poerwandari \& Akmal, 2000: 436). Dalam konteks Indonesia, terbatasnya akses perempuan terhadap fasilitas pelayanan kesehatan reproduksi yang berkualita terutama bagi perempuan miskin di Daerah Tertinggal, Terpencil, Perbatasan dan Kepulauan (DTPK) merupakan salah satu tantangan yang dihadapi dalam pencapaian MDGs 5 Target 5A (Bappenas, 2010: 90). Dalam laporannya, Bappenas (2010: 72) menyimpulkan penyediaan fasilitas PONEK, PONED, Posyandu, dan unit transfusi darah belum merata dan belum seluruhnya terjangkau oleh seluruh penduduk. Selain itu, sistem rujukan dari rumah ke puskesmas dan ke rumah sakit juga belum berjalan dengan optimal serta akses jalan yang buruk ke tempat pelayanan kesehatan, ditambah pula adanya faktor budaya di daerah tertentu.

Secara lebih rinci, analisis yang dilakukan oleh WHO terhadap kaitan antara gender dan kesehatan menunjukkan adanya 3 faktor yang berdampak terhadap status kesehatan perempuan, yaitu: (1) perbedaan biologis; (2) perbedaan sosial budaya; dan (3) akses dan kontrol terhadap sumber daya. Perbedaan biologis meliputi: anatomis; fisiologis; genetik; dan sistem imunitas, sedangkan perbedaan sosial budaya meliputi: peran dan tanggung jawab; norma (adat dan agama); ekspektasi masyarakat/keluarga; dan identitas subjektif. Adapun akses dan kontrol terhadap sumber daya meliputi: ekonomi; sosial; politik; ketersediaan dan kualitas informasi dan edukasi tentang kesehatan reproduksi; ketersediaan waktu untuk berpartisipasi dalam program kesehatan; ketersediaan dan kualitas layanan; keterbatasan sumber daya internal; otoritas terhadap tubuh sendiri untuk memilih layanan yang diinginkan; dan kontrol atas pengambilan keputusan dan keterampilan untuk mencegah komplikasi penyakit.

Sistem kesehatan di Indonesia terdiri dari pelayanan kesehatan yang disediakan oleh pihak swasta dan pemerintah atau dikenal dengan 
istilah pelayanan kesehatan publik/masyarakat (Mundayat, 2010: 325). Kementerian Kesehatan dan pemerintah di tingkat daerah bertanggung jawab untuk menyediakan pelayanan publik dalam bidang kesehatan, termasuk membuat peraturan dan memberikan akreditasi kepada pihak swasta dalam memberikan pelayanan kesehatan. Berdasarkan Undang-Undang Nomor 23 Tahun 2014 tentang Pemerintahan Daerah Pasal 12 ayat (1), bidang kesehatan merupakan salah satu bidang urusan pemerintahan wajib yang berkaitan dengan pelayanan dasar yang menjadi kewenangan pemerintah daerah.

\section{Angka Kematian Ibu dan Program Keluarga Harapan}

Upaya penurunan AKI merupakan salah satu target Kementerian Kesehatan, yang dapat dilihat dari berbagai program yang telah dilaksanakan selama beberapa dekade terakhir. Salah satunya adalah melalui Program Perencanaan Persalinan dan Pencegahan Komplikasi (P4K) dan Bantuan Operasional Kesehatan (BOK) ke puskesmas di kabupaten/kota (Pusat Komunikasi Publik Sekretariat Jenderal Kementerian Kesehatan, 2010). Sebelum MDGs ditetapkan, Pemerintah juga telah melaksanakan berbagai program untuk menurunkan AKI. Pada tahun 1990 Kementerian Kesehatan telah meluncurkan safe motherhood initiative, sebuah program yang memastikan semua perempuan mendapatkan perawatan yang dibutuhkan sehingga selamat dan sehat selama kehamilan dan persalinannya. Upaya tersebut dilanjutkan dengan program Gerakan Sayang Ibu pada tahun 1996 yang dicanangkan langsung oleh Presiden yang melibatkan sektor lain di luar kesehatan (Mi'raj, 2017: 4).

Selain itu, salah satu program utama yang ditujukan untuk mengatasi masalah kematian ibu yaitu penempatan bidan di tingkat desa secara besar-besaran yang bertujuan untuk mendekatkan akses pelayanan kesehatan ibu dan bayi baru lahir kepada masyarakat. Upaya lain yang telah dilakukan yaitu strategi Making Pregnancy Safer yang dicanangkan pada tahun 2000. Selanjutnya pada tahun 2012 Kementerian Kesehatan juga meluncurkan Program Expanding Maternal and Neonatal Survival (EMAS) dalam rangka menurunkan AKI dan neonatal sebesar 25\% (Rahmi, 2016: 3).

Di samping upaya yang dilakukan oleh Kementerian Kesehatan melalui berbagai program dan kegiatan untuk menurunkan AKI tersebut, PKH yang mulai dilaksanakan pada tahun 2007 oleh Pemerintah melalui Kementerian Sosial dapat dikatakan mendukung upaya penurunan AKI, karena salah satu fokusnya adalah ibu hamil yang terdapat dalam rumah tangga miskin. PKH adalah sebuah program pemberian bantuan sosial bersyarat kepada Keluarga Miskin (KM) yang ditetapkan sebagai Keluarga Penerima Manfaat (KPM) (“Tentang Program," 2018). Dalam program ini setiap KPM menerima bantuan sosial yang terdiri dari 4 komponen, yaitu: (1) Bantuan uang tunai per tahun, sebesar Rp1.890.000 untuk KPM reguler dan Rp2.000.000 untuk KPM Lanjut Usia, KPM Penyandang Disabilitas, dan KPM di Papua dan Papua Barat; (2) Pendampingan sosial; (3) Pelayanan di fasilitas pelayanan kesehatan, pendidikan, dan kesejahteraan sosial; dan (4) Program bantuan komplementer di bidang pangan, kesehatan, pendidikan, subsidi energi, ekonomi, perumahan, dan pemenuhan kebutuhan dasar lainnya.

Sebagai sebuah program bantuan bersyarat, PKH membuka akses keluarga miskin, terutama ibu hamil dan anak untuk memanfaatkan berbagai fasilitas pelayanan kesehatan dan fasilitas layanan pendidikan yang tersedia di sekitar mereka. Manfaat PKH juga mulai didorong untuk mencakup penyandang disabilitas dan lanjut usia dengan mempertahankan taraf kesejahteraan sosialnya sesuai dengan amanat konstitusi. Di beberapa negara, program perlindungan sosial yang juga dikenal dengan istilah Conditional Cash Transfers (CCT) ini terbukti cukup berhasil dalam menanggulangi kemiskinan, terutama masalah kemiskinan kronis ("Tentang Program," 2018).

Melalui PKH, KPM didorong untuk memiliki akses dan memanfaatkan pelayanan sosial dasar kesehatan, pendidikan, pangan dan gizi, perawatan, dan pendampingan, termasuk akses terhadap berbagai program 
perlindungan sosial lainnya yang merupakan program komplementer secara berkelanjutan. Bahkan PKH diarahkan untuk menjadi center of excellence penanggulangan kemiskinan yang menyinergikan berbagai program perlindungan dan pemberdayaan sosial nasional. Misi besar PKH adalah untuk menurunkan kemiskinan. Jumlah penduduk miskin Indonesia sampai pada Maret tahun 2016 masih sebesar 10,86\% dari total penduduk atau 28,01 juta jiwa (BPS, 2016). Pemerintah telah menetapkan target penurunan kemiskinan menjadi $7-8 \%$ pada tahun 2019, sebagaimana tertuang di dalam RPJMN 20152019. PKH diharapkan dapat berkontribusi secara signifikan untuk menurunkan jumlah penduduk miskin, menurunkan kesenjangan (gini ratio) sekaligus meningkatkan Indeks Pembangunan Manusia (IPM). Pada tahun 2018 Pemerintah memperluas cakupan penerima bantuan PKH menjadi 10 juta orang penerima, naik dari 6 juta pada tahun 2017 (Nurdin, 2017).

Terdapat 3 aspek yang menjadi fokus dalam PKH, yaitu kesehatan, pendidikan, dan kesejahteraan sosial. Aspek kesehatan ini sangat terkait erat dengan upaya untuk menurunkan AKI dan Angka Kematian Bayi (AKB). Rendahnya penghasilan menyebabkan KM tidak mampu memenuhi kebutuhan kesehatan dan pendidikan, bahkan untuk tingkat minimal sekalipun. Pemeliharaan kesehatan ibu hamil yang tidak memadai berakibat pada buruknya kondisi kesehatan bayi yang dilahirkan dan seringkali menyebabkan tingginya kematian bayi. Sasaran PKH merupakan keluarga miskin dan rentan yang terdaftar dalam Data Terpadu Program Penanganan Fakir Miskin yang memiliki komponen kesehatan, pendidikan, dan kesejahteraan sosial. KPM PKH harus terdaftar dan hadir pada fasilitas kesehatan dan pendidikan terdekat. Kewajiban KPM PKH di bidang kesehatan meliputi pemeriksaan kandungan bagi ibu hamil, pemberian asupan gizi dan imunisasi serta timbang badan anak balita dan anak prasekolah.

Berdasarkan buku Profil Kesehatan Indonesia, data AKI merupakan indikator yang efektif untuk menilai kesehatan ibu. Melalui data tersebut diketahui bahwa sejak tahun 1991, AKI di Indonesia pada mulanya sudah sangat tinggi. Namun demikian, kondisi ini dapat terus menurun hingga tahun 2007. Pada tahun 2012 angka ini kembali meningkat secara signifikan, dan angkanya dapat terus ditekan hingga tahun 2015. Berdasarkan survei penduduk antar sensus tahun 2015, AKI mencapai 305 kematian ibu per 100.000 kelahiran hidup. Walaupun demikian, hal tersebut belum mencapai angka komitmen Pemerintah untuk tahun 2015, yakni 102 kematian per 100.000 kelahiran hidup. Akses terhadap fasilitas pelayanan kesehatan akan memberikan kontribusi yang cukup besar untuk menekan AKI. Hal ini dilakukan antara lain dengan mendorong ibu hamil untuk mengakses fasilitas pelayanan kesehatan dan melibatkan tenaga medis profesional dalam proses dan pascakelahiran.

\section{Peran PKH dalam Penurunan AKI}

Keberadaan ibu hamil dalam keluarga yang menjadi KPM merupakan salah satu syarat agar sebuah keluarga dalam RTM dapat menerima $\mathrm{PKH}$, selain adanya anak yang masih berstatus sebagai pelajar atau siswa. Temuan lapangan di Provinsi Jambi menunjukkan bahwa persentase ibu hamil yang menjadi penerima PKH masih relatif rendah, seperti terlihat pada tabel 1 .

Berdasarkan Tabel 1 dapat diketahui bahwa dari 106.755 KPM, terdapat 1.651 KPM yang memiliki ibu hamil di dalamnya, atau sekitar 1,5\%. Apabila dilihat per kabupaten/ kota, persentasenya berkisar antara 1,2\% hingga 2,5\%. Persentase KPM yang memiliki ibu hamil tertinggi ada di Kabupaten Tanjung Jabung Barat, sementara yang terendah ada di 3 wilayah, yaitu Kabupaten Kerinci, Kota Jambi, dan Kabupaten Tanjung Jabung Timur.

Sementara itu, jumlah ibu hamil yang menjadi KPM di Provinsi Kalimantan Selatan dapat dilihat pada Tabel 2. Terlihat bahwa secara umum persentase ibu hamil yang menjadi penerima KPM di Provinsi Kalimantan Selatan lebih rendah daripada di Provinsi Jambi. Apabila dilihat per kabupaten/kota, persentasenya berkisar antara $0,6 \%$ hingga $2,6 \%$. Persentase 
Tabel 1. Jumlah Ibu Hamil dalam KPM PKH Tahap II Tahun 2018 Provinsi Jambi

\begin{tabular}{lll}
\hline Kabupaten/Kota & Jumlah KPM & Jumlah Ibu Hamil (\%) \\
\hline Batanghari & 10.341 & $201(1,9)$ \\
Bungo & 7.290 & $113(1,6)$ \\
Kerinci & 13.998 & $166(1,2)$ \\
Jambi & 16.318 & $188(1,2)$ \\
Sungai Penuh & 2.186 & $30(1,4)$ \\
Merangin & 11.727 & $226(1,9)$ \\
Muaro Jambi & 10.128 & $144(1,4)$ \\
Sarolangun & 9.948 & $150(1,5)$ \\
Tanjung Jabung Barat & 9.767 & $246(2,5)$ \\
Tanjung Jabung Timur & 7.796 & $95(1,2)$ \\
Tebo & 7.260 & $92(1,3)$ \\
Jumlah & & 25.925 .487 \\
\hline Sumber: Dinas Sojit, Kep &
\end{tabular}

Sumber: Dinas Sosial, Kependudukan, dan Catatan Sipil Provinsi Jambi, 2018.

Tabel 2. Jumlah KPM dan Ibu Hamil dalam program PKH di Provinsi Kalimantan Selatan

\begin{tabular}{lllllll}
\hline \multirow{2}{*}{ Kabupaten/Kota } & \multicolumn{3}{c}{ Jumlah KPM } & \multicolumn{3}{c}{ Jumlah Ibu Hamil (\%) } \\
\cline { 2 - 7 } & Tahap I & Tahap II & Tahap III & Tahap I & Tahap II & Tahap III \\
\hline Banjarmasin & 17.253 & 16.340 & 15.335 & $107(0,6)$ & $104(0,6)$ & $95(0,6)$ \\
Banjarbaru & 5.985 & 5.920 & 5.793 & $75(1,3)$ & $84(1,4)$ & $89(1,5)$ \\
Banjar & 14.589 & 14.153 & 13.813 & $145(1,0)$ & $143(1,0)$ & $181(1,3)$ \\
Barito Kuala & 10.496 & 10.456 & 10.131 & $139(1,3)$ & $147(1,4)$ & $135(1,3)$ \\
Tanah Laut & 7.320 & 7.303 & 7.031 & $64(0,9)$ & $68(0,9)$ & $81(1,2)$ \\
Tanah Bumbu & 6.623 & 6.597 & 6.176 & $49(0,7)$ & $50(0,8)$ & $51(0,8)$ \\
Kotabaru & 5.528 & 5.506 & 5.466 & $145(2,6)$ & $118(2,1)$ & $96(1,8)$ \\
Tapin & 4.321 & 4.288 & 4.250 & $49(1,1)$ & $52(1,2)$ & $56(1,3)$ \\
Hulu Sungai Selatan & 9.364 & 9.323 & 8.697 & $129(1,4)$ & $130(1,4)$ & $101(1,2)$ \\
Hulu Sungai Tengah & 8.881 & 8.844 & 8.786 & $141(1,6)$ & $133(1,5)$ & $137(1,6)$ \\
Hulu Sungai Utara & 11.042 & 11.021 & 10.758 & $160(1,4)$ & $165(1,5)$ & $125(1,2)$ \\
Balangan & 3.913 & 3.883 & 3.813 & $59(1,5)$ & $59(1,5)$ & $65(1,7)$ \\
Tabalong & 6.743 & 6.721 & 6.534 & $61(0,9)$ & $60(0,9)$ & $49(0,7)$ \\
\hline
\end{tabular}

Sumber: Bidang Perlindungan Jaminan Sosial, Dinas Sosial Provinsi Kalimantan Selatan, 2018 (diolah).

KPM yang memiliki ibu hamil tertinggi ada di Kabupaten Kotabaru, sementara yang terendah ada di 3 wilayah, yaitu Kabupaten Tanah Bumbu, Kota Banjarmasin, dan Kabupaten Tabalong.

Adapun bila dilihat dari jumlah kematian ibu, terdapat penurunan jumlah kematian ibu dari tahun ke tahun, baik di Provinsi Jambi maupun Provinsi Kalimantan Selatan sebagaimana terlihat pada Tabel 3 dan Tabel 4.

Dari Tabel 3 dapat dilihat bahwa secara umum di Provinsi Jambi terdapat penurunan jumlah kematian ibu dari tahun 2012 hingga tahun 2017, yaitu dari 77 menjadi 54. Penurunan ini menurut narasumber dari Dinas Kesehatan Provinsi Jambi tidak berkaitan secara langsung dengan keberadaan PKH. Penulis sependapat dengan narasumber, karena terjadi peningkatan kasus pada tahun 2015 dan 2016, masing-masing sebesar 56 dan 59. Dengan demikian dapat dikatakan bahwa penurunan yang terjadi masih landai dan belum terjadi percepatan, mengingat jumlah kematian ibu masih cenderung naik turun setiap tahun.

Demikian pula di Provinsi Kalimantan Selatan, meskipun penulis hanya berhasil mendapatkan data dalam rentang waktu 3 tahun 
Tabel 3. Jumlah Kematian Ibu Provinsi Jambi Tahun 2012-2017

\begin{tabular}{lcccccc}
\hline \multirow{2}{*}{ Kabupaten/Kota } & \multicolumn{7}{c}{ Tahun } \\
\cline { 2 - 7 } \multicolumn{1}{c}{} & $\mathbf{2 0 1 2}$ & $\mathbf{2 0 1 3}$ & $\mathbf{2 0 1 4}$ & $\mathbf{2 0 1 5}$ & $\mathbf{2 0 1 6}$ & $\mathbf{2 0 1 7}$ \\
\hline Kerinci & 10 & 5 & 3 & 6 & 6 & 4 \\
Merangin & 16 & 12 & 8 & 10 & 6 & 5 \\
Sarolangun & 7 & 6 & 5 & 3 & 5 & 4 \\
Batanghari & 4 & 3 & 2 & 4 & 2 & 8 \\
Bungo & 3 & 6 & 5 & 8 & 10 & 5 \\
Tebo & 6 & 6 & 4 & 2 & 9 & 4 \\
Muaro Jambi & 7 & 5 & 3 & 6 & 3 & 5 \\
Tanjab Barat & 5 & 5 & 5 & 3 & 5 & 7 \\
Tanjab Timur & 10 & 6 & 5 & 5 & 8 & 6 \\
Kota Jambi & 8 & 4 & 9 & 7 & 3 & 4 \\
Kota Sei Penuh & 1 & 0 & 4 & 2 & 2 & 2 \\
JUMLAH & 77 & 58 & 53 & 56 & 59 & 54 \\
\hline SUM
\end{tabular}

Sumber: Dinas Kesehatan Provinsi Jambi, 2108.

Tabel 4. Jumlah Kematian Ibu Provinsi Kalimantan Selatan Tahun 2015-2017

\begin{tabular}{lccc}
\hline \multirow{2}{*}{ Kabupaten/Kota } & \multicolumn{3}{c}{ Tahun } \\
\cline { 2 - 4 } & $\mathbf{2 0 1 5}$ & $\mathbf{2 0 1 6}$ & $\mathbf{2 0 1 7}$ \\
\hline Banjarmasin & 14 & 6 & 6 \\
Banjarbaru & 13 & 5 & 6 \\
Banjar & 25 & 11 & 10 \\
Barito Kuala & 10 & 6 & 5 \\
Tapin & 5 & 7 & 1 \\
Hulu Sungai Selatan & 8 & 4 & 5 \\
Hulu Sungai Tengah & 12 & 8 & 7 \\
Hulu Sungai Utara & 4 & 3 & 6 \\
Balangan & 7 & 2 & 4 \\
Tabalong & 7 & 6 & 7 \\
Tanah Laut & 6 & 8 & 1 \\
Tanah Bumbu & 7 & 6 & 4 \\
Kotabaru & 2 & 9 & 13 \\
Jumlah & 120 & 81 & 75 \\
\hline Sumber: Dinas Kesentan Provinsi Kalimantan Selatan & 2018 (diolab)
\end{tabular}

Sumber: Dinas Kesehatan Provinsi Kalimantan Selatan, 2018 (diolah).

(2015-2017), tidak seperti Provinsi Jambi di mana data yang tersedia adalah dalam rentang waktu 6 tahun (2012-2017). Berdasarkan data pada Tabel 4 , terdapat penurunan jumlah kematian ibu dari tahun 2015 hingga 2017, dari 120 menjadi 75. Namun agak berbeda dengan Provinsi Jambi, jumlah kematian ibu di Provinsi Kalimantan Selatan cenderung turun setiap tahun. Meskipun demikian, narasumber dari Dinas Kesehatan Provinsi Jambi yaitu Kepala Bidang Kesehatan Masyarakat (Kabid Kesmas), menyampaikan bahwa kasus kematian ibu yang ada dalam data tersebut disusun berdasarkan laporan dari fasilitas pelayanan kesehatan (facility based data). Dengan demikian masih ada kemungkinan kasus kematian ibu yang belum dilaporkan. Angka ini diperbarui setiap tahun pada bulan Desember sehingga angka untuk tahun 2018 belum ada.

Terkait dengan hubungan antara PKH dan penurunan AKI, menurut Kabid Kesmas Dinas Kesehatan Provinsi Jambi, sasaran PKH adalah rumah tangga miskin yang memiliki anak usia 0 sampai dengan 15 tahun dan ibu hamil atau menyusui. Dengan demikian manfaat PKH harus 
dikaitkan dengan sasaran tersebut, termasuk manfaat PKH dalam penurunan AKI. Apabila dana yang diterima dari PKH dibelanjakan untuk konsumsi makanan yang dapat meningkatkan status gizi ibu hamil, maka baru dapat dikatakan bahwa PKH memiliki hubungan dengan penurunan AKI. Dijelaskan oleh narasumber bahwa beberapa di antara penyebab pendarahan ketika melahirkan adalah Kekurangan Energi Kronis (KEK) dan anemia. Meningkatnya status gizi ibu hamil, sehingga ibu hamil tidak mengalami KEK dan menderita anemia, tentu saja akan berpengaruh pada menurunnya risiko perdarahan ketika melahirkan dan pada gilirannya dapat mengurangi AKI. Sebagaimana diketahui, perdarahan merupakan penyebab utama tingginya AKI, sementara itu anemia dan KEK merupakan penyebab utama terjadinya perdarahan dan infeksi (Indriani, 2012:2). KEK, terutama yang kemungkinan disebabkan karena adanya ketidakseimbangan asupan gizi (energi dan protein), sehingga zat gizi yang dibutuhkan tubuh tidak tercukupi pada ibu hamil, juga dapat berisiko pada kematian ibu mendadak pada masa perinatal atau risiko melahirkan Bayi dengan Berat Lahir Rendah/ BBLR (Agustia, 2010: ix).

Di Provinsi Jambi, perdarahan juga masih menjadi penyebab utama kematian ibu. Pada tahun 2016, 32\% kematian ibu disebabkan oleh perdarahan. Jumlah ini meningkat di tahun 2017 menjadi $46 \%$. Penyebab kematian ibu lainnya adalah hipertensi dalam kehamilan, gangguan metabolik, infeksi, gangguan sistem peredaran darah, dan lainlain sebagaimana terlihat pada Tabel 5.
Tidak adanya ketentuan yang mengatur mengenai jumlah dana yang harus dibelanjakan oleh ibu hamil juga disampaikan oleh Suhana, ibu hamil penerima PKH di Kelurahan Teluk Kenali, Aur Duri, Kota Jambi. Suhana berusia 27 tahun dan telah dua kali menerima PKH. Ketika dilakukan wawancara, usia kandungannya sudah 9 bulan, merupakan kehamilan anak yang kedua, sementara anak pertamanya sudah kelas 4 Sekolah Dasar. Sebelum hamil, ia bekerja sebagai pekerja rumah tangga. Menurut narasumber, dana yang diterima dari PKH digunakan untuk kebutuhan hidup sehari-hari dan membiayai sekolah anaknya. Dengan demikian tidak ada anggaran yang dikhususkan untuk membeli makanan yang ditujukan untuk meningkatkan gizi bagi ibu hamil. Sebagaimana ibu hamil lainnya, ia juga mengikuti kelas ibu hamil dan menerima tablet tambah darah dari Puskesmas setempat, yaitu Puskesmas Aur Duri.

Dengan demikian jelas bahwa tidak terdapat hubungan langsung antara $\mathrm{PKH}$ dan penurunan AKI. Meskipun ibu hamil merupakan salah satu sasaran $\mathrm{PKH}$, namun tidak ada ketentuan mengenai persentase dana yang harus dibelanjakan untuk konsumsi makanan ibu hamil yang dapat meningkatkan status gizi ibu hamil sehingga terhindar dari KEK dan anemia yang menjadi penyebab utama terjadinya perdarahan pada ibu melahirkan. Oleh karena itu, agar PKH lebih efektif dalam menurunkan AKI, seharusnya ada ketentuan yang mengatur mengenai persentase dana yang dimanfaatkan untuk konsumsi ibu hamil.

Tabel 5. Penyebab Kematian Ibu di Provinsi Jambi

\begin{tabular}{llll}
\hline \multicolumn{1}{c}{ Tahun 2016 } & & \multicolumn{2}{c}{ Tahun 2017 } \\
\hline Perdarahan & $32 \%$ & Perdarahan & $46 \%$ \\
Hipertensi dalam kehamilan & $25 \%$ & Hipertensi dalam kehamilan & $9 \%$ \\
Gangguan metabolik & $9 \%$ & Gangguan metabolik & $7 \%$ \\
Infeksi & $5 \%$ & Infeksi & $3 \%$ \\
Gangguan sistem peredaran darah (jantung, & $2 \%$ & Gangguan sistem peredaran darah (jantung, & $7 \%$ \\
stroke, dll) & & stroke, dll) & $28 \%$ \\
Lain-lain & $27 \%$ & Lain-lain & \\
Sumbr: Din
\end{tabular}




\section{Upaya untuk Menurunkan AKI}

Untuk menurunkan AKI, berdasarkan wawancara dengan Kabid Kesmas Dinas Kesehatan Provinsi Jambi, Dinas Kesehatan pemerintah daerah telah melakukan beberapa upaya, antara lain pemberian tablet tambah darah. Upaya ini dilaksanakan sesuai dengan Peraturan Menteri Kesehatan Republik Indonesia Nomor 88 Tahun 2014 tentang Standar Tablet Tambah Darah bagi Wanita Usia Subur dan Ibu Hamil. Selain itu, terdapat Program Perencanaan Persalinan dan Pencegahan Komplikasi (P4K) yang telah dilaksanakan sejak tahun 2010 dan merupakan program 100 hari Kementerian Kesehatan. Terdapat pula Kelas Ibu Hamil, yang juga merupakan program dari Kementerian Kesehatan. Terkait dengan peningkatan sumber daya manusia, juga telah dilakukan pelatihan kepada bidan di Puskesmas dan Desa.

Sementara di Provinsi Kalimantan Selatan, hasil wawancara dengan Kepala Seksi Promosi Kesehatan dan Pemasyarakatan Dinas Kesehatan Provinsi Kalimantan Selatan, diperoleh penjelasan mengenai beberapa upaya yang telah dilakukan untuk menurunkan AKI. Sebelum tahun 1998, telah terdapat Program Mother Care yang dilaksanakan di 3 kabupaten. Setelah program ini selesai, dilanjutkan pada 13 kabupaten lainnya yang ada di seluruh wilayah provinsi ini. Khusus untuk wilayah pedesaan, terdapat Pos Kesehatan Desa (Poskedes). Salah satu kegiatan dari Poskedes adalah kesiapsiagaan dalam melayani ibu hamil melalui pemanfaatan Buku KIA (Kesehatan Ibu dan Anak) dan pemasangan stiker P4K. Poskedes ini juga dilengkapi dengan stok darah, ambulans, dan keterangan mengenai siapa pengambil keputusan (ibu, suami, atau mertua) jika sewaktu-waktu ibu hamil akan melahirkan atau mengalami sesuatu yang berkaitan dengan kehamilannya. Di provinsi ini juga dibentuk Kelas Ibu Hamil yang ada di setiap Puskesmas. Untuk mengatasi kendala geografis, mengingat wilayah Provinsi Kalimantan Selatan yang luas dan belum semua memiliki akses kepada fasilitas kesehatan, dibangun Rumah Tunggu Kelahiran (RTK). Namun demikian belum semua lokasi di wilayah terpencil dan jauh dari fasilitas kesehatan memiliki RTK.
Mengacu pada hasil Konferensi ICPD di Kairo padatahun 1994, pelayanan sebelum, semasa kehamilan, dan pascakehamilan merupakan salah satu dari 10 program kesehatan reproduksi yang harus diperhatikan oleh semua negara. Selain itu, hak untuk mendapat pelayanan yang berkaitan dengan fungsi reproduksi juga termasuk ke dalam salah satu hak kesehatan reproduksi perempuan yang diakui dalam Deklarasi ICPD. Oleh karena itu, menjadi kewajiban pemerintah untuk terus meningkatkan upaya penyediaan akses ibu hamil terhadap pelayanan yang dibutuhkan selama kehamilan dan melahirkan. Terkait dengan $\mathrm{PKH}$, upaya itu dapat dilakukan melalui penambahan jumlah ibu hamil yang menjadi anggota KPM sebagai penerima bantuan program tersebut.

Upaya ini perlu dilakukan karena sebagaimana hasil analisis yang dilakukan oleh WHO, akses dan kontrol terhadap sumber daya merupakan salah satu faktor yang mempengaruhi status kesehatan perempuan. Dalam konteks ini, akses dan kontrol terhadap ketersediaan dan kualitas layanan ibu hamil menjadi salah satu faktor yang mempengaruhi status kesehatan ibu hamil. Semakin banyak ibu hamil yang menjadi penerima bantuan dalam $\mathrm{PKH}$, maka akses dan kontrol ibu hamil terhadap pelayanan yang dibutuhkannya selama kehamilan hingga dan pascamelahirkan akan semakin bertambah. Meningkatnya jumlah dan kualitas layanan terhadap ibu hamil tersebut pada akhirnya akan berdampak pada kualitas kesehatan ibu hamil, sehingga diharapkan AKI juga akan semakin berkurang.

\section{Kesimpulan dan Rekomendasi}

Tidak terdapat kaitan secara langsung antara PKH dan penurunan $\mathrm{AKI}$, mengingat tidak ada ketentuan yang rinci mengenai persentase uang tunai yang diterima dari PKH yang harus dibelanjakan untuk meningkatkan kualitas gizi ibu hamil penerima PKH, yang pada akhirnya akan berpengaruh pada kualitas kesehatan ibu hamil dan penurunan AKI. Kewajiban untuk memeriksakan diri minimal 4 kali selama kehamilan juga belum dilaksanakan oleh semua ibu hamil penerima PKH. 
Di Provinsi Jambi dan Provinsi Kalimantan Selatan tidak ada program khusus yang ditujukan untuk ibu hamil penerima $\mathrm{PKH}$. Meskipun demikian di dua provinsi tersebut telah dilakukan beberapa upaya untuk meningkatkan kualitas kesehatan dan gizi ibu hamil yang menjadi program Kementerian Kesehatan, yaitu melalui pemberian tablet tambah darah dan biskuit serta penyelenggaraan Kelas Ibu Hamil.

Untuk meningkatkan efektivitas $\mathrm{PKH}$ dalam menurunkan AKI, perlu dilakukan pendampingan dan monitoring secara berkala kepada ibu hamil penerima PKH mengenai konsumsi makanan yang dibutuhkan oleh ibu hamil dan kewajiban untuk melakukan pemeriksaan minimal 4 kali selama kehamilan. Selain itu, persentase ibu hamil penerima PKH dalam KPM perlu ditingkatkan. Semakin banyak ibu hamil yang menjadi penerima bantuan dalam PKH, maka akses dan kontrol ibu hamil terhadap pelayanan yang dibutuhkannya selama kehamilan hingga dan pasca-melahirkan akan semakin bertambah. Meningkatnya jumlah dan kualitas layanan terhadap ibu hamil tersebut pada akhirnya akan berdampak pada kualitas kesehatan ibu hamil, sehingga diharapkan AKI juga akan semakin berkurang.

\section{DAFTAR PUSTAKA}

Agustia, E. N. (2010). Hubungan antara Asupan Protein dengan Kekurangan Energi Kronik (KEK) pada Ibu Hamil di Kecamatan Jebres Surakarta (Karya Tulis Ilmiah). Program Studi D IV Kebidanan Fakultas Kedokteran Universitas Sebelas Maret Surakarta, diakses dari https:// core.ac.uk/download/pdf/12345215.pdf.

Aristia, R. (2011). Faktor yang Mempengaruhi Kematian Ibu Hamil di Jawa Timur dengan Menggunakan Geographically Weighted Poisson Regression (Tugas Akhir StatistikaFMIPA). Institut Teknologi Sepuluh Nopember, Surabaya.

Badan Penelitian dan Pengembangan Kesehatan Kementerian Kesehatan. (2010). Riset Kesehatan Dasar (Riskesdas) 2010. Jakarta: Badan Penelitian dan Pengembangan Kesehatan Kementerian Kesehatan.
Badan Perencanaan Pembangunan Nasional (Bappenas). (2010). Laporan Pencapaian Tujuan Pembangunan Milenium di Indonesia. Jakarta: Badan Perencanaan Pembangunan Nasional (Bappenas).

Fauzi, Y. (2017, Maret 22). Ranking Indeks Pembangunan Manusia Indonesia Turun ke-113. Diakses dari https://www.cnnindonesia.com/ekon omi/20170322182446-78-202081/ranking-indekspembangunan-manusia-indonesia-turun-ke-113, pada 5 April 2018.

Habsjah, A. (2008). Kesehatan Perempuan: Perspektif Feminis. Jurnal Perempuan (61): Pendidikan, Media dan Gender.

Hoelman, M. B., dkk. (2015). Panduan SDGs untuk Pemerintah Daerah (Kota dan Kabupaten) dan Pemangku Kepentingan Daerah. Jakarta: INFID.

Indriani, N. (2012). Analisis Faktor-faktor yang Berhubungan dengan Preeklamsia/Eklamsia pada Ibu Bersalin di Rumah Sakit Umum Daerah Kardinah Kota Tegal Tahun 2011 (Skripsi). Fakultas Kesehatan Masyarakat, Program Studi Kebidanan Komunitas, Universitas Indonesia.

Kementerian Kesehatan Republik Indonesia. (2017). Profil Kesehatan Indonesia Tahun 2016. Jakarta: Kementerian Kesehatan Republik Indonesia.

Lubis, F. (2000). Ibu Omas dan Gerakan Kesehatan Reproduksi di Tanah Air, dalam Sita van Bemmelen, Atashendartini Habsjah, Lugina Setyawati (ed.), Benih Bertumbuh, Kumpulan Karangan untuk Prof. Tapi Omas Ihromi. Yogyakarta: Yayasan Galang.

Machfiroh, A. (2015). Efektivitas Program Nasional Pemberdayaan Masyarakat Mandiri Perkotaan PNPM-MP) di Kota Palu. Katalogis, 3(2) 2015.

Mi'raj, M. W. (2017). Implementasi Gerakan Sayang Ibu (GSI) di Desa Tasik Seminai Kecamatan Koto Gasib Tahun 2015, Jurusan Ilmu Pemerintahan Fakultas Ilmu Sosial dan Ilmu Politik Universitas Riau, JOM FISIP, 4(1) Februari 2017.

Mosse, J. C. (2007). Gender dan Pembangunan (Cetakan V). Yogyakarta: Pustaka Pelajar.

Mundayat, A. A. dkk. (2010). Target MDGs Menurunkan Angka Kematian Ibu Tahun 2015 Sulit Dicapai. Jakarta: Women Research Institute.

Nurdin, N. (2017, Oktober 9). Penerima PKH Tahun Depan Naik Jadi 10 Juta Jiwa. Diakses dari https://regional.kompas.com/ read/2017/10/09/18133261/penerima-pkh-tahundepan-naik-jadi-10-juta-jiwa, pada 5 April 2018. 
Pertiwi, L. D. (2012). Spatial Durbin Model untuk Mengidentifikasi Faktor-Faktor yang Mempengaruhi Kematian Ibu di Jawa Timur (Tugas Akhir Statistika-FMIPA). Surabaya: Institut Teknologi Sepuluh Nopember.

Poerwandari, E. K. \& Akmal, Y. (2000). Kondisi Sosial-Budaya Suku Sentani dan Implikasinya pada Kesehatan Reproduksi Perempuan, dalam E. Kristi Poerwandari dan Rahayu Surtiati Hidayat (ed), Perempuan Indonesia dalam Masyarakat yang Tengah Berubah, 10 Tahun Program Kajian Wanita. Jakarta: Program Studi Kajian Wanita Program Pascasarjana Universitas Indonesia.

Pusat Komunikasi Publik Sekretariat Jenderal Kementerian Kesehatan. (2010, Februari 3). Untuk Menurunkan Angka Kematian Ibu dan Kematian Bayi Perlu Kerja Keras. Diakses dari http://www.depkes.go.id/development/site/jkn/ index.php?cid=793\&id=untuk-menurunkanangka-kematian-ibu-dan-kematian-bayi-perlukerja-keras.html, pada 5 April 2018.

Rahman, A. (2006). Hukum dan Hak Kesehatan Reproduksi Perempuan: Masalah Aborsi, dalam Sulistyowati Irianto (ed), Perempuan dan Hukum: Menuju Hukum yang Berperspektif Kesetaraan dan Keadilan. Jakarta: Yayasan Obor Indonesia.

Rahmi, F. L. (2016). Implementasi Program EMAS (Expanding Maternal And Neonatal Survival) sebagai Upaya Penurunan Angka Kematian Ibu dan Bayi Baru Lahir di Kabupaten Tegal. Journal of Politic and Government Studies, 5(3) 2016, 51-60.

Sari, A. N. (2016). Path analysis model estimates using generalized method of moment: Case study Maternal mortality in the Province of East Java. Jurnal Matematika dan Pendidikan Matematika, I(2) September, 119-132.

Suharyono, A. (2010). Faktor-Faktor yang Mempengaruhi Keberhasilan Implementasi Program Keluarga Harapan (PKH) dalam Penurunan Angka Kematian Ibu (AKI) Di Kecamatan Ngoro Kabupaten Jombang (Tesis). Universitas Airlangga, Surabaya.

Tentang Program Keluarga Harapan. Diakses dari http://keluargaharapan.com/tentang-programkeluarga-harapan/, pada 4 April 2018.

Wahyuni, B. (1997). Alat Kontrasepsi dan Kesehatan Reproduksi, Jurnal Perempuan (04): Rahim Ini Milik Siapa?. 